\title{
DATELINE/
} \section{SANDOZ BUYS INTO SYSTEMIX}

NEW YORK - Last year saw continued consolidation of the U.S. biotechnology sector, with Sandoz's (Basel, Switzerland) December purchase of 60 percent of SyStemix (Palo Alto, CA) the latest in a series of deals. Earlier in 1991, American Home Products (New York) bought 60 percent of Genetics Institute (Cambridge, MA), and Chiron merged with Cetus, its neighbor in Emeryville, CA. These purchases followed 1990's blockbuster, when Hoffmann-La Roche (Basel, Switzerland) bought 60 percent of Genentech (So. San Francisco, CA).

At least one Wall Street analyst foresees further consolidation, particularly among biotech companies. Denise Gilbert, a biotechnology analyst at Smith Barney (San Francisco, CA), sees firsttier biotech companies increasingly buying out their third-tier counterparts. Among a group of 50 biopharmaceutical firms followed by Gilbert, the top eight firms have each bankrolled about $\$ 350$ million, while the bottom 20 companies have only squirreled away about $\$ 45$ million apiece. "As the leading companies look to expand their product pipelines they'll turn to smaller companies," says Gilbert. "But they'll likely wait until 1993, when the smaller companies are starved for cash."

Perhaps the latest deal's biggest surprise was Sandoz's high valuation of SyStemix. Sandoz's \$392 million offer for 60 percent of SyStemix values the company at $\$ 650$ million. "The value is so far out of line with valuations of similar-stage companies that we view the transaction as a one-time unique event, not as a transaction that will revalue other biotech companies," says Teena Lerner, a Shearson Lehman Brothers (New York) biotech analyst. At the time of the deal, SyStemix's market value totaled $\$ 260$ million, a value already near the high end of valuations for earlystage companies without products in clinical trials, Lerner adds. In comparison, Chiron's acquisition of Cetus valued Cetus at $\$ 660$ million, yet Cetus brought with it $\$ 300$ million in cash, about 600 employees, and a 20 -year history. SyStemix, for its part, brings to Sandoz $\$ 30$ million, around 85 employees, and three years as an ongoing company.

Sandoz will purchase SyStemix stock. It will buy 4 million existing shares by tender offer for $\$ 70$ a share, or $\$ 280$ million, and 2 million newly issued shares for $\$ 56$ a share, or $\$ 111$ million. Sandoz has the option to buy the rest of SyStemix after three years, if SyStemix's independent directors approve.

\section{Sandoz's push into biotechnology}

The SyStemix purchase continues Sandoz's push into biotechnology. It comes as part of a \$1-billion, five-year investment initiative in the technology, which includes some $\$ 200$ million in investments prior to SyStemix. Among these are:

-A \$22-million, four-year research agreement with Gensia Pharmaceuticals (San Diego, CA) begun in January to develop drugs to treat Type II diabetes mellitus. -A \$13.5-million, three-year research collaboration with Genetic Therapy (Gaithersburg, MD) entered into last November to develop gene-transfer technology in immunology/inflammation, cancer, and cardiovascular disease.

-A \$30-million, five-year research agreement with Cytel (La Jolla, CA) begun in 1989 to develop drugs against autoimmune diseases and tissue rejection in organ-transplant patients.

Sandoz sees the SyStemix deal expanding "significantly our research capabilities in immunology and oncology," says Max Link, chief executive officer of Sandoz Pharma, Sandoz's pharmaceutical division. Sandoz-made up of six divisions-racked up $\$ 625$ million in profits in 1990 on sales of $\$ 8.9$ billion.

\section{Stem cells are key}

Key to SyStemix is its stem-cell technology. Stem cells-which make up less than 0.5 percent of bone-marrow cellsgive rise to all blood cells, including red blood cells, platelets, and the immune system's T cells and B cells. Purified stem cells could offer an advantage over current bone-marrow transplants used to treat many advanced cancers. About 60 percent of autologous transplants fail because hidden cancer cells in the patients' extracted marrow cause relapses. And 50 percent of allogenic transplants fail because hidden $\mathrm{T}$ cells in donor marrow cause rejections. Presumably, purified stem cells wouldn't contain cancer cells or T cells.

SyStemix potentially has a strong patent position in stem cells. It received a U.S. patent last October covering both the cellular composition of human stem cells and their separation from bone marrow. Yet patents covering human cells - a basic building block of lifeare generally challenged and often overturned.

Another SyStemix advantage is that the U.S. Food and Drug Administration
(FDA, Bethesda, MD) currently doesn't oversee its technology. Historically, FDA hasn't regulated bone-marrow transplants or other organ transplants. "But any change in FDA regulations could delay SyStemix's commercialization efforts by as long as two years," says Stuart Weisbrod, a biotech analyst at Merrill Lynch (New York).

\section{Plenty of competition}

SyStemix has plenty of competition, though. Several biotech companies are developing stem-cell purification processes, including CellPro (Bothell, WA) and Applied Immune Sciences (Menlo Park, CA). And some of the leading biopharmaceutical companies-like Amgen (Thousand Oaks, CA), Immunex (Seattle, WA), and Genetics Instituteare working on stem-cell growth factors. SyStemix plans to start clinical trials of its stem-cell technology early this year. The trials will involve leukemia patients who will have their bone marrow removed before receiving extensive chemotherapy and radiation to destroy cancer cells. The patients will then receive their purified stem cells in hopes that the cells will produce new blood and immune cells. SyStemix plans to market in 1993 its autologous bone-marrow transplant, which will cost about $\$ 7,500$ a patient.

SyStemix is also developing megakaryocytes, precursor cells that differentiate into blood-clotting platelets. The technology could replace the use of donated blood transfusions-about 3 million of which occured in the U.S. in 1990 - to boost patient clotting ability. SyStemix believes using a patient's own megakaryocytes could eliminate current transfusion problems like contamination with infectious organisms, rejection of donor platelets, and the need for repeated infusions. It expects the technology, which will run around $\$ 1,000$ a patient, to reach the market by 1995 . "The megakaryocyte project could ultimately provide the greatest commercial potential for SyStemix," says Merrill Lynch's Weisbrod.

In SyStemix, Sandoz is likely purchasing a winner. Weisbrod, for one, believes SyStemix — which lost $\$ 7.4$ million in 1990-will turn a profit by 1994 . And at least one SyStemix executive likes the buyout. "Even in our wildest dreams we couldn't have imagined such a good deal," says Mike McCune, vice president of the firm's new enterprise research division.

-B.J. Spalding 